\title{
O ALCANCE DO DIREITO AO "ESQUECIMENTO" NO ORDENAMENTO JURÍDICO BRASILEIRO EM RELAÇÃO AO CONTROLE DE DADOS DAS PESSOAS FÍSICAS NA INTERNET ${ }^{1}$
}

THE REACH OF THE RIGHT TO “FORGETTING” IN BRAZILIAN LEGAL ORDINATION IN RELATION TO THE CONTROL OF DATA ON PERSONS ON THE INTERNET

Rafaella Couto FERREIRA ${ }^{2}$

ISSUE DOI: $10.21207 / 2675-0104.2019 .947$

\begin{abstract}
RESUMO
A presente pesquisa tem como objetivo geral analisar o alcance do direito ao esquecimento na internet tendo em vista o ordenamento jurídico brasileiro e os dados pessoais da pessoa física. Para isto, através de pesquisa bibliográfica, pelo método hipotético dedutivo, conclui-se que a ausência de uma previsão legal específica não constitui óbice ao seu reconhecimento. No entanto, ressalta-se a importância de estabelecer um instrumento legal específico para uma maior efetivação deste direito, de modo a estabelecer também as suas limitações e prevenir o risco de discricionariedade em sua aplicação, em prol da liberdade de expressão, direito à informação e memória coletiva.
\end{abstract}

Palavras-chave: Direito ao esquecimento. Sociedade de Informação. Internet. Controle autoinformativo.

ABSTRACT

This current research aims to analyze the scope of the right to be forgotten on the Internet, given the Brazilian legal system and the personal data of the individual. For this, through bibliographical research, by the hypothetic-deductive method, it is concluded that the absence of a specific legal

\footnotetext{
${ }^{1} \mathrm{O}$ presente artigo sintetiza a monografia de conclusão da pesquisa, realizada para o Programa Interno de Bolsas de Iniciação Científica (PIBIC 2018-2019) da Faculdade de Direito de Franca (FDF), Franca/SP.

${ }^{2}$ Discente da Faculdade de Direito de Franca (FDF), Franca/SP. Bolsista do Programa Interno de Bolsas de Iniciação Científica (PIBIC 2018-2019).
} 
provision is not an obstacle to its recognition. Nonetheless, the importance of establishing a specific legal instrument for the further enforcement of this right should be noted, so as to establish its limitations and prevent the risk of discretion in its application, in favor of freedom of expression, right to information and collective memory.

Keywords: Right to forgetfulness. Information society. Internet. Self-informative control.

\section{INTRODUÇÃO}

A presente pesquisa tem como contexto a atual conjuntura social, política e econômica, que fora impactada por uma alteração na dinâmica em relação à transmissão e armazenamento de informações, sendo conhecida, portanto, como Sociedade de Informação. Em sua era digital, houve uma ascensão quantitativa quanto a estrutura de armazenamento da informação, bem como quanto a instantaneidade de sua transmissão. Atrelado a isso, a informação é propagada por meio da internet, formada por redes interligadas, por meio de diversas espécies de provedores de serviços, que inclusive, facilitam a sua localização.

Desse modo, considerando esse cenário marcado pelo fenômeno do "informacionismo", como assim conceitua Manuel Castells em sua obra "Sociedade em Rede" ao definir a informação como elemento estruturante da sociedade atual ${ }^{3}$, houve a desintegração da noção de esfera privada e pública, á partir da veiculação de dados pessoais na internet, de modo a implicar a construção de um legado coletivo de memórias em um espaço atemporal e de alcance instantâneo, que coloca em debate a forma pelo qual o individuo lida com o binômio memória e esquecimento.

Em razão disto, diante da incerteza e instabilidade da informação em meio digital, de modo a afetar o livre desenvolvimento da personalidade do indivíduo, a problemática tem como enfoque o controle de dados pretéritos das pessoas físicas armazenados na internet, conhecida como a tese do direito ao esquecimento.

A previsão e discussão do direito ao esquecimento, em função da exposição do indivíduo, têm raízes no instituto da ressocialização dos jurisdicionados que foram condenados, mas já cumpriram a pena e desejam que a imprensa não mais relembre a opinião pública desses fatos passados, de modo que seja possível a eles retornarem ao convívio social sem um julgamento social eterno e as consequências advindas disso.

\footnotetext{
${ }^{3}$ CASTELLS, Manuel. A sociedade em rede. 3. ed. São Paulo: Paz e Terra, 2000.
} 
O direito ao esquecimento, independente da mídia em que a tese se concentra, está fundado por valores constitucionais consistentes na inviolabilidade da vida privada e na sua colisão com a liberdade de expressão. No entanto, quando a discussão é transposta ao ambiente virtual, o debate permeia novos contornos em razão da complexidade técnica do processo de informação neste ambiente.

Por esse viés, o jurisdicionando deseja ter o controle da veiculação de determinada informação, por meio de sua retificação, remoção ou desindexação, que em decorrência do transcurso do tempo, tornou-se desatualizada ou irrelevante, de modo afetar o seu desenvolvimento como pessoa humana em caráter perpétuo, em razão das características que a informação possui no ambiente digital.

Nesse sentido, estuda-se como objetivo geral na presente pesquisa o alcance do direito ao esquecimento na internet acerca dos dados pessoais das pessoas físicas, tendo em vista as previsões existentes no ordenamento jurídico brasileiro. Para isso, o trabalho de pesquisa teve como norte objetivos específicos, consubstanciados na análise das relações subjetivas dos indivíduos na Sociedade de Informação com a memória; o debate das peculiaridades do direito ao esquecimento na internet; a análise semântica do termo, a fim de estudar se este seria um conceito adequado; a averiguação do fundamento de existência; a conceituação dos pleitos decorrentes: retificação, remoção e desindexação de dados pessoais, as suas relações com as legislações brasileiras existentes e com a Lei Geral de Proteção de Dados, que entrará em vigor no ano de 2020; a exploração dos valores constitucionais envolvidos no tema; o debate do conceito de interesse público e de critérios de aplicação e efetividade, e por fim, a análise dos elementos de duas decisões judiciais proferidas, recentemente, pelo Superior Tribunal de Justiça sobre o tema.

Para alcançar os objetivos propostos, a elaboração da pesquisa tem como base o método de pesquisa bibliográfica, embasada em análise de doutrina e decisões judiciais, pelo método hipotético dedutivo. O primeiro capítulo abarca o estudo sobre o contexto em que a problemática da pesquisa se insere, bem como as suas raízes, natureza jurídica, análise conceitual, os pleitos decorrentes e as legislações pátrias relacionadas. $\mathrm{O}$ segundo capítulo, objetiva fundamentar os valores constitucionais envolvidos, as suas ressignificações diante da era digital, os possíveis critérios de ponderação e exposição de questões acerca da aplicação e efetividade do direito. Por fim, no terceiro capítulo, analisa-se a delimitação do tema por meio da comparação de duas decisões judiciais 
recentes do Superior Tribunal de Justiça envolvendo o pleito do direito ao "esquecimento" a pessoas físicas no ambiente digital: Agravo Interno no Recurso Especial 1.593.873 - SP (2016/0079618-1) e Recurso Especial 1.660 .168 - RJ (2014/0291777-1), de modo a coletar os elementos presentes em cada acordão.

\section{O INDIVÍDUO E A SOCIEDADE DE INFORMAÇÃO: A MEMÓRIA NA ERA DIGITAL}

Com a finalidade de investigar as interações sociais, econômicas, culturais e políticas do indivíduo inserido em uma organização social pautada pelo meio ambiente virtual, é necessário partir da premissa que independente da época em que se concentra o objeto de estudo, há um ponto comum entre elas: o elemento principal em que ela se funda e estrutura ${ }^{4}$. Assim sendo, em substituição aos recursos que estruturavam as sociedades agrícolas, industrial e pós-industrial ${ }^{5}$, tais como a terra, máquinas a vapor, eletricidade e a prestação de serviços, têm-se que a informação se tornou o elemento principal pelo qual se estrutura a atual organização social ${ }^{6}$, desde o telégrafo elétrico ${ }^{7}$ até o meio ambiente virtual, o qual respectiva transição consiste o que se chama de "sociedade de informação"8.

Nesse sentido, a sociedade de informação em sua era digital, propulsionada pela evolução tecnológica, com a computação eletrônica e a Internet, e formada a partir da democratização de acesso a esses meios, trouxe um novo dinamismo pela forma a qual as informações são difundidas, tendo como consequência novos paradigmas relacionados ao acúmulo de memórias. O meio ambiente virtual fez com que a informação que outrora era transmitida e armazenada por papéis ${ }^{9}$ passou a ser transmitida pela tecnologia dos bits. O bit consiste em ser "a menor unidade

\footnotetext{
${ }^{4}$ BIONI, Bruno Ricardo. Proteção de dados pessoais: a função e os limites do consentimento. 1. ed. Rio de Janeiro: Forense, 2019, p. 3

${ }^{5}$ PAESANI, Liliana Minardi. O direito na sociedade de informação. 1. ed. São Paulo: Atlas, 2007, p. XI.

${ }^{6}$ CASTELLS, Manuel. A sociedade em rede. 3. ed. São Paulo: Paz e Terra, 2000.

${ }^{7}$ AMARAL, J. F. D. Economia da informação e do conhecimento. 10. ed. Coimbra: Almedina, 2007, p. 88

${ }^{8}$ BIONI, Bruno Ricardo. Proteção de dados pessoais: a função e os limites do consentimento. 1. ed. Rio de Janeiro: Forense, 2019, p. 5

${ }^{9}$ BIONI, Bruno Ricardo. Proteção de dados pessoais: a função e os limites do consentimento. 1. ed. Rio de Janeiro: Forense, 2019, p. 6
} 
de medida de transmissão de dados usada na computação e informática" 10 que, em conjunto de dados, permite o computador processar, armazenar ou até facilitar a própria busca das informações, seja até em seu formado de áudio ou vídeo ${ }^{11}$.

Á partir da técnica binária, a informação é processada e acumulada com muito mais intensidade do que no passado, a partir deste novo suporte e, conjugado com a arquitetura da Internet, formada por redes interligadas, as informações transmitidas na rede passaram a possuir quatro características: instantaneidade, amplitude em seu alcance, a possibilidade de armazenamento ilimitado, de modo que um conteúdo pode permanecer por um tempo indefinido nesta mesma estrutura, e facilidade em seu acesso, bastando utilizar-se de um mecanismo de busca a partir de palavras-chaves.

Atrelado a isto, o conteúdo é difundido na internet por meio de diversas espécies de provedores de serviços, que de modo genérico define como o "conjunto de funcionalidades que podem ser acessadas por meio de um terminal conectado à internet", seja pessoa natural ou jurídica. Nesse sentido, há os provedores de serviços que fazem tratamento de dados, sendo capazes de criar conteúdo, de divulgá-los, mesmo que seja conteúdo de terceiros, e até facilitar a localização de outros provedores a partir de mecanismos, como os provedores de informação, conteúdo e de busca.

Consequentemente, com a conjunção dos provedores de serviço, a internet tornou-se um meio de construção coletiva de conhecimentos e memórias produzidas pelos indivíduos inseridos no meio ambiente virtual. Neste espaço há a difusão de informações de cunho educativo, político, artístico, informativo e até pessoais, proporcionada pelas mídias sociais, onde é nítido em seus espaços, como pontua Sérgio Branco ${ }^{12}$ "o deslocamento para o ambiente público de atos que eram eminentemente privados", incidindo a relativização da noção de espaço público e privado, como também afirma Melina Ferracini Moraes:

O público e o privado não estão separados em sua atuação; porque um indivíduo pode expor a sua vida privada em um espaço público, mas pode ser que a esfera pública persiga tal sujeito, revelando, sem

\footnotetext{
${ }^{10}$ TECMUNDO. O que é Bit?. Disponível em: https://www.tecmundo.com.br/programacao/227-o-que-ebit-htm. Acesso em: 8 ago. 2019.

${ }^{11}$ BIONI, Bruno Ricardo. Proteção de dados pessoais: a função e os limites do consentimento. 1. ed. Rio de Janeiro: Forense, 2019, p. 7

${ }^{12}$ BRANCO, Sérgio. Memória e esquecimento na internet. $1^{\circ}$. ed. Porto Alegre - RS: Arquipélago Editorial LTDA., 2017, p. 11.
} 
o seu consentimento, dados, informações e fatos que ele não deseja expor. $^{13}$

Isso implica dizer que o novo dinamismo trazido pela forma e o meio pelo qual as informações são difundidas no ambiente digital tem como consequência novos paradigmas relacionados ao acúmulo de memórias, fundada em uma mudança comportamental e que implica em uma construção de um legado coletivo de memórias em um espaço atemporal e de alcance instantâneo, que coloca em debate a forma pelo qual a pessoa humana lida com o binômio memória e esquecimento.

Simultaneamente, ambos possuem a sua importância, relacionadas respectivamente ao direito à informação e tutela do livre desenvolvimento da personalidade. Nesse sentido, o escritor George Orwell, em sua obra 1984, propõe uma reflexão sobre os efeitos da vigilância e, ao mesmo tempo, medidas de controle da informação e apagamento da história, para uma finalidade de dominação: "quem controla o passado controla o futuro; quem controla o presente controla o passado"14, estabelecido pelo Estado. Atualmente, pode-se estender o controle não só ao poder estatal, como ao poder privado, ligado as grandes corporações. Por este viés, afirma-se que um Estado Democrático é aquele que protege os direitos individuais em toda a sua totalidade, conjugando proteções, no que diz respeito às circulações das informações. Ou seja, deve a permitir a segurança em relação às informações pessoais dos cidadãos e, ao mesmo tempo, garantir transparência em relação às informações relevantes ao Poder Político.

Concomitantemente, existe a noção de que o esquecimento é fundamental para a convivência social saudável entre os indivíduos ${ }^{15}$, de modo que seja o meio necessário para que a pessoa humana possa se reconstruir socialmente, afastada dos fatos passados e desconexos com a atual realidade. Tal ideia está intimamente ligada a ideia de privacidade, que é inerente a pessoa humana, pois é um desejo biológico, que se manifesta institivamente. Enquanto ser social, o individuo tem necessidade de compartilhar voluntariamente na internet o que está fazendo ou pensando, por exemplo, mas igualmente e simultaneamente, possui de modo inevitável para garantir a sua liberdade e realização um meio ou local

\footnotetext{
${ }^{13}$ MORAES, Melina Ferracini. O direito ao esquecimento na internet no contexto das decisões judiciais no Brasil. 2016. 140 f. Tese (Mestrado em Direito Político e Econômico) - Universidade Presbiteriana Mackenzie, São Paulo, 2016. p. 17.

${ }^{14}$ ORWELL, George. 1984. 9. ed. São Paulo: Companhia das Letras, 2017, p. 40.

${ }^{15}$ IZQUIERDO, Iván. Memória. $2^{a}$ ed. Porto Alegre: ArtMed, 2002, p. 20.
} 
pelo qual permita que se sinta livre para exercer a sua esfera íntima e estar livre dos julgamentos inquisitivos de terceiros ${ }^{16}$

A exposição na rede seja de fatos pessoais ou relacionados a episódios ocorridos no passado e divulgados por terceiros em razão do seu caráter informativo, mas que possuem uma carga social atualmente, de modo que implique em arrependimento ou impedimento para seguir a própria vida normalmente, afetam a imagem e honra, em um ambiente que se tornou a narrativa coletiva da sociedade e informações são localizáveis com facilidade. Nesse sentido, a pessoa humana carrega dentro de si o desejo de ter autocontrole sobre os seus dados. Sabe-se que mesmo se a pessoa não tiver acesso à internet ou uma conta em rede social, com certeza ainda terá vestígios nela nesse espaço, de alguma forma, pela possibilidade de registro por um terceiro. Temos, assim, um arquivamento forçado, de modo que é impossível um indivíduo tornar os fatos da sua vida invisíveis ${ }^{17}$.

À vista disso, se a "busca da felicidade inclui uma parcela de satisfação com o olhar do outro" 18 e, a partir disso, surge à esperança da pessoa humana de ter controle sobre certas passagens passadas da sua vida, considerando os obstáculos que existem para excluir uma informação da rede, indaga-se: a internet consegue esquecer e de qual forma?

A aplicação de uma medida de remoção ou desindexação de conteúdo do meio digital, de modo a tutelar essa necessidade, possui limites quando se confronta com importância da memória e o caráter democrático que a internet ganhou ao possibilitar o compartilhamento de informações a nível global. Surge a partir disso, uma ferramenta democrática, que permite a autonomia dos cidadãos para obter informações e, ao mesmo tempo, exercer a sua cidadania. Para isso, é fundamental que o ambiente seja transparente e que, se por um lado o cidadão tenha o direito à autodeterminação informativa, em prol da democracia, há o direito em favor da coletividade de ver divulgadas determinadas notícias. Isto implica, em uma sociedade democrática, em distribuição de $\operatorname{poder}^{19}$.

\footnotetext{
16 TED. Why Matters? https://www.ted.com/talks/glenn_greenwald_why_privacy_matters?language=pt-br. Acesso em: 5 jul. 2019.

${ }^{17}$ BRANCO, Sérgio. Memória e esquecimento na internet. $1^{\circ}$. ed. Porto Alegre - RS: Arquipélago Editorial LTDA., 2017, p. 61.

${ }^{18}$ FREUD. Sigmund. O mal-estar na civilização. São Paulo: Penguin Classics Companhia das Letras, 2011, p. 28.

${ }^{19}$ RODOTÁ, Stefano. A vida na sociedade de vigilância: a privacidade hoje. 1. ed. São Paulo: Renovar, 2008 , p. 45.
} 
A informação tem diferentes dimensões quanto ao seu valor, que podem ser: econômico, de controle social, democrático, de construção da memória e social, de modo que sua difusão implica aos direitos da personalidade da pessoa humana. Desse modo, no que tange a isso surge a esperança pelo individuo de controle desses dados diante da incerteza e instabilidade da informação em meio digital.

\subsection{A TUTELA DO DIREITO AO "ESQUECIMENTO”}

\subsubsection{O DIREITO AO ESQUECIMENTO EM SENTIDO ESTRITO E AS SUAS DISTINÇÕES EM DECORRÊNCIA DA TRANSPOSIÇÃO AO AMBIENTE VIRTUAL}

Apesar das relações subjetivas do indivíduo com as novas tecnologias surgidas durante o período conhecido como "sociedade da informação", com destaque para a computação eletrônica e a internet, têmse muito antes a discussão acerca da relação entre os direitos da personalidade, que conferem identidade a pessoa humana, e as suas exposições pelas mídias tradicionais (revistas, jornais, rádio) e mídias televisivas. Segundo Patrícia Peck Pinheiro, a tutela do direito ao esquecimento pode se conceituar em:

$\mathrm{O}$ direito que qualquer ser humano possui de ter qualquer fato vexaminoso ligado a sua vida que afete diariamente sua reputação ser esquecido depois de um determinado lapso de tempo pela população através da não veiculação das informações sobre o fato pelas mídias. ${ }^{20}$

Complementa-se que não se restringe a discussão em todos os casos acerca de uma conduta de arrependimento sobre aquela informação, mas sim o modo e a finalidade pelo qual são lembrados ${ }^{21}$, de modo a incidir no desejo de não interferência e "ser prejudicial ao seu convívio em

\footnotetext{
${ }^{20}$ PINHEIRO, Patricia Peck. Direito Digital. 6. ed. São Paulo: Saraiva, 2018, p. 490.

${ }^{21}$ SCHREIBER, Anderson. Direitos da personalidade. 2. ed. São Paulo: Atlas, 2013, p. 171.
} 
sociedade ou em razão de expor fato ou característica que não mais se coaduna com a identidade por ela construída",22.

$\mathrm{O}$ debate tem origem aos jurisdicionados que foram condenados, mas já cumpriram a pena, e desejam que a imprensa não mais relembre a opinião pública desses fatos passados, de modo que seja possível a eles reconstruírem a suas vidas sem um julgamento social eterno e as consequências advindas disso. Nesse sentido, pode citar ainda a preocupação do direito em relação à estabilização do passado, para uma segurança em relação ao futuro, com os institutos do sigilo da folha de antecedentes e a exclusão dos registros da condenação com a finalidade de reabilitação do condenado, previstos nos artigos 93 do Código Penal, artigo 748 do Código de Processo Penal e artigo 202 da Lei de Execuções Penais.

Em vista disso, não obstante os mesmos valores constitucionais e elementos inerentes independente da mídia em que for aplicada, a extensão da tutela do direito ao esquecimento na internet é distinta ${ }^{23}$, por questões de índole técnica, conforme pontua Daniel Sarmento, em seu parecer nomeado de "Liberdades Comunicativas e "Direito ao Esquecimento" na ordem constitucional brasileira":

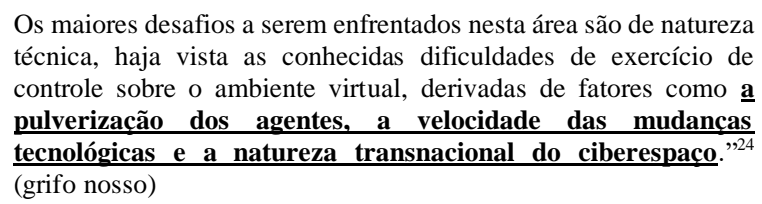

Desse modo, no ambiente digital o controle da informação é dificultado pela facilidade pelo qual ela pode ser transmitida, com ou sem o consentimento do titular, por diferentes agentes distintos, bem como circulando internacionalmente por meio de servidores localizados em diferentes países, impondo obstáculos relacionados à soberania dos Estados-nações.

\footnotetext{
${ }^{22}$ ITS RIO. Amicus curiae - Direito ao Esquecimento no STF. Disponível em: https://itsrio.org/wpcontent/uploads/2018/05/amicus-curiae-instituto-tecnologia-direito-ao-esquecimento.pdf. Acesso em: 20 nov. 2018.

${ }^{23}$ INTERNETLAB. Direito ao esquecimento: entre liberdade de expressão e direitos da personalidade. Entrevista com Julia Powles. Disponível em: http://www.internetlab.org.br/wpcontent/uploads/2017/01/ENTREVISTA_JULIA_POWLES_v04.pdf. Acesso em: 2 jul. 2019.

${ }^{24}$ SARMENTO, Daniel. Liberdades Comunicativas e "Direito ao Esquecimento" na ordem constitucional brasileira. Revista Brasileira de Direito Civil. v. 7, n. 01, jan-mar. 2016, p. 45.
} 


\subsubsection{A ANÁLISE SEMÂNTICA DO DIREITO AO ESQUECIMENTO: FUNDAMENTOS DE EXISTÊNCIA E ADEQUAÇÃO}

Diante do exposto acerca da efetividade do direito quando aplicado no ambiente digital, a referência ao direito ao esquecimento, como um suposto direito, se deve ao fato de que a sua existência, nos parâmetros e finalidade que a ideia de sua nomenclatura perpassa, é controversa no meio jurídico.

O reconhecimento do direito ao esquecimento passar a ser fundamentado ao direito à privacidade, ligada principalmente ao âmbito digital, sendo necessária a sua aplicação ser constituída restritivamente, de forma a evitar os riscos de uma aplicação equivocada. Nesse sentido, entende-se que é possível o reconhecimento da tutela nos casos individuais, de pessoas anônimas e, consequente, sem envolvimento de interesse público, sempre que isso violar preceitos constitucionais da personalidade da pessoa humana, tendo em vista à proteção de dados pessoais ${ }^{25}$ abarcando, deste modo, também o âmbito cível.

Segundo as elucidações de Julia Powles da Universidade de Cambridge, uma nomenclatura mais adequada para o direito ao esquecimento, seria o direito de não ser lembrado ${ }^{26}$. Esta ideia se deve ao fato de que a promessa de um esquecimento efetivo, por questões técnicas, é impossível no âmbito digital. E até na consciência da pessoa humana, sendo que o direito não pode prometer o esquecimento ${ }^{27}$, mas pode impedir a pessoa humana reviver constantemente informações incorretas, desatualizadas e irrelevantes a sociedade ${ }^{28}$. Considera-se que não se trata propriamente de reescrever o passado, mas sim ter controle dos próprios fatos, que lhe dizem respeito e impedem a seguir na construção de sua história, relacionado, deste modo, como um direito à esperança e consoante

\footnotetext{
${ }^{25}$ SARMENTO, Daniel. Liberdades Comunicativas e "Direito ao Esquecimento" na ordem constitucional brasileira. Revista Brasileira de Direito Civil. v. 7, n. 01, jan-mar. 2016, p. 6.

26 INTERNETLAB. Direito ao esquecimento: entre liberdade de expressão e direitos da personalidade. Entrevista com Julia Powles. Disponível em: http://www.internetlab.org.br/wpcontent/uploads/2017/01/ENTREVISTA_JULIA_POWLES_v04.pdf. Acesso em: 2 jul. 2019.

27 ITS RIO. Amicus curiae - Direito ao Esquecimento no STF. Disponível em: https://itsrio.org/wpcontent/uploads/2018/05/amicus-curiae-instituto-tecnologia-direito-ao-esquecimento.pdf. Acesso em: 20 nov. 2018.

28 INTERNETLAB. Direito ao esquecimento: entre liberdade de expressão e direitos da personalidade. Entrevista com Julia Powles. Disponível em: http://www.internetlab.org.br/wpcontent/uploads/2017/01/ENTREVISTA_JULIA_POWLES_v04.pdf. Acesso em: 2 jul. 2019.
} 
com a dignidade da pessoa humana ${ }^{29}$, entendimento este consoante também com o Enunciado 531 da VI Jornada de Direito Civil, que incluiu o direito ao esquecimento na tutela da dignidade da pessoa humana na sociedade de informação.

Desse modo, este entendimento segue a ideia de que se a sociedade se transforma, o direito deve acompanhá-la. $O$ direito não pode se confundir com a lei ${ }^{30}$, tendo o direito ao esquecimento, ou independente da nomenclatura mais adequada que dê nome a tese, esta encontra respaldo em valores constitucionais.

\subsubsection{OS CONCEITOS DERIVADOS DA NOMENCLATURA DO DIREITO AO ESQUECIMENTO: RETIFICAÇÃO, ELIMINAÇÃO E DESINDEXAÇÃO DE DADOS PESSOAIS}

A nomenclatura "direito ao esquecimento" pode ser entendida como um gênero ${ }^{31}$ que abrange vários tipos de pleitos para alcançar o seu sentido em comum. Na era digital, a tutela também se estende ao pleito da remoção, retificação e desindexação da informação na internet, através dos provedores de aplicações e de pesquisa ${ }^{32}$, que possuem as suas próprias particularidades e efetividades em relação ao direito.

O pleito de remoção e retificação dos dados pessoais se refere como o próprio nome diz, ao apagamento ou correção de informações em razão do modo e finalidade pelo qual estão vinculadas. Quanto a desindexação, esta se refere a retirada de resultados específicos em provedores de busca, a fim de dificultar o acesso de determinadas informações pelo qual o individuo quer tero seu nome desvinculado. Desse modo, o conteúdo continuará armazenado no provedor em que está

\footnotetext{
${ }^{29}$ MARTINI, Sandra Regina.; BERGSTEIN, Laís. Aproximações entre o direito ao esquecimento e a lei geral de proteção de dados pessoais (LGPD). Revista Científica Disruptiva, v. 1, n. 1, p. 160176, 29 jun. 2019, p. 165.

${ }^{30}$ MARTINI, Sandra Regina; BERGSTEIN, Laís. Aproximações entre o direito ao esquecimento e a lei geral de proteção de dados pessoais (LGPD). Revista Científica Disruptiva, v. 1, n. 1, p. 160176, 29 jun. 2019, p. 162.

31 INTERNETLAB. Direito ao esquecimento: entre liberdade de expressão e direitos da personalidade. Entrevista com Julia Powles. Disponível em: http://www.internetlab.org.br/wpcontent/uploads/2017/01/ENTREVISTA_JULIA_POWLES_v04.pdf. Acesso em: 2 jul. 2019.

${ }^{32}$ ITS RIO. Amicus curiae - Direito ao Esquecimento no STF. Disponível em: https://itsrio.org/wpcontent/uploads/2018/05/amicus-curiae-instituto-tecnologia-direito-ao-esquecimento.pdf. Acesso em: 20 nov. 2018.
} 
inserido, no entanto, estará "obscuro" no âmbito digital, pois os provedores de busca atuam como intermediários de informações na internet.

Ressalta-se que, de modo genérico, o direito ao esquecimento encontra-se fundamento no ordenamento jurídico brasileiro no direito de proteção á vida privada. No entanto, no entanto, de modo específico ainda não é previsto. Há legislações infraconstitucionais que guardam relações com os pleitos associados ao termo do "direito ao esquecimento", porém são insuficientes para aplicá-lo de modo efetivo.

No que diz respeito à remoção e retificação, este já encontra as suas origens a partir de resquícios no ordenamento jurídico brasileiro no Código de Defesa do Consumidor (CDC), primeira lei infraconstitucional que trata da tutela da proteção da privacidade em face da pessoa humana ${ }^{33}$, ao estabelecer critérios aos "Bancos de Dados e Cadastros de Consumidores", garantindo ao consumidor acesso e controle às suas próprias informações, em visto os efeitos que a publicidade de uma informação em um cadastro possa ter no futuro.

Além disso, há aproximações genéricas deste pleito pelo Marco Civil da Internet (Lei 12.965/2014). A lei assegura o direito do usuário a "inviolabilidade da intimidade e da vida privada, sua proteção e indenização pelo dano material ou moral decorrente de sua violação.", em seu artigo $7^{\circ}$, inciso I. Já no inciso $\mathrm{X}$ do mesmo dispositivo, versa sobre a exclusão definitiva de dados pessoais a que tiver fornecido à determinada aplicação de internet, a seu requerimento, ao término das relações entre as partes, ressalvadas as hipóteses de guarda obrigatórias previstas na mesma lei. Bem como, em seus artigos $19^{\circ}$ a $21^{\circ}$, asseguram a responsabilidade dos provedores de aplicações de internet por danos de conteúdo gerado por terceiros. Segundo o professor Sérgio Branco, as hipóteses de exclusão previstas no Marco Civil da Internet, não constituem fundamento para o direito ao esquecimento, pois se tratam de outras hipóteses, como contratuais, ou hipóteses com campo de atuação mais amplo ${ }^{34}$. No mesmo sentido, Melina Ferracini Moraes afirma que "o Marco Civil da Internet estabelece, de forma genérica, a proteção da privacidade dos dados

\footnotetext{
${ }^{33}$ BRANCO, Sérgio. Memória e esquecimento na internet. $1^{\circ}$. ed. Porto Alegre - RS: Arquipélago Editorial LTDA., 2017, p. 147.

${ }^{34}$ BRANCO, Sérgio. Memória e esquecimento na internet. $1^{\circ}$. ed. Porto Alegre - RS: Arquipélago Editorial LTDA., 2017, p. 179.
} 
pessoais, mas não determina, de forma explícita, a exclusão por conteúdos que venham a ferir tal direito" 35 .

Considerando a premissa que nos provedores de aplicações de internet em que haja remuneração indireta, nos termos do artigo $3^{\circ}, \S 2^{\circ}$, do Código de Defesa do Consumidor, há uma relação de consumo e contratual $^{36}$ e desse modo, incidiria a hipótese do artigo $7^{\circ}$, inciso $X$, por abarcar uma relação contratual. No entanto, mesmo utilizando a previsão para a aplicação do direito ao esquecimento na internet, configura-se incompleta, pois abarca somente aqueles casos em que a informação fora consentida, mas não quer mais manter a relação com o provedor ${ }^{37}$.

Especificadamente quanto ao provedor de busca, este tem como função organizar todo o conteúdo armazenado na internet, de modo a permitir com mais facilidade a localização de conteúdos específicos armazenados em provedores de conteúdo. Em regra, o seu funcionamento está constituído em quatro etapas: recolhimento, armazenamento, indexação e ordenação, e apresentação ${ }^{38}$ das URL's. A questão é que esse serviço não é aleatório: há algoritmos que filtram os resultados a partir de fórmulas de programação apontados pelos programadores que combinam vários critérios entre si: frequência de termos, quantidade de links que levam aquela página, a influência do local do termo buscado em sua estrutura, análise da relevância da URL, propriamente dita ${ }^{39}$. Neste sentido, considera-se que a "fase de ordenação é o ponto chave dos motores de busca, pois é o que determina para o usuário qual dos motores disponíveis no mercado é o melhor."40. Desse modo, observa-se que apesar das alegações dos motores de busca de que seriam provedores neutros ${ }^{41}$, pela análise da sistemática de seu funcionamento, verifica-se a presença de um

\footnotetext{
${ }^{35}$ MORAES, Melina Ferracini. O direito ao esquecimento na internet no contexto das decisões judiciais no Brasil. 2016. 140 f. Tese (Mestrado em Direito Político e Econômico) - Universidade Presbiteriana Mackenzie, São Paulo, 2016, p. 96.

${ }^{36}$ FIORILLO, Celso Antônio Pacheco. O Marco Civil da Internet e o Meio Ambiente Digital na Sociedade de Informação: comentários à Lei no 12.965/2014. São Paulo: Saraiva, 2015, p. 58.

${ }^{37}$ MORAES, Melina Ferracini. $O$ direito ao esquecimento na internet no contexto das decisões judiciais no Brasil. 2016. 140 f. Tese (Mestrado em Direito Político e Econômico) - Universidade Presbiteriana Mackenzie, São Paulo, 2016, p. 99.

${ }^{38}$ BENEVIDES, N.; SILVESTRE, G. O Papel do Google na Eficácia do Direito ao Esquecimento - Análise Comparativa Entre Brasil e Europa. Revista de Direito Privado, v. 70, out. 2016, p. 3.

${ }^{39}$ BENEVIDES, N.; SILVESTRE, G. O Papel do Google na Eficácia do Direito ao Esquecimento - Análise Comparativa Entre Brasil e Europa. Revista de Direito Privado, v. 70, out. 2016, p. 4.

${ }^{40}$ BENEVIDES, N.; SILVESTRE, G. O Papel do Google na Eficácia do Direito ao Esquecimento - Análise Comparativa Entre Brasil e Europa. Revista de Direito Privado, v. 70, out. 2016, p. 4.

${ }^{41}$ BENEVIDES, N.; SILVESTRE, G. O Papel do Google na Eficácia do Direito ao Esquecimento - Análise Comparativa Entre Brasil e Europa. Revista de Direito Privado, v. 70, out. 2016, p. 5.
} 
tratamento de dados para fornecer o melhor serviço de acordo com o que espera a sociedade, sendo possível a sua responsabilidade em "suprimir alguns resultados exibidos quando preenchidos os requisitos estipulados" ${ }^{\prime 2}$.

Nesse sentido, mesmo que os provedores de busca não assegurem um direito ao esquecimento de fato a determinada informação, a sua sistemática facilita o acesso a determinado conteúdo através de combinações de algoritmos que podem ligar a informações pretéritas cuja atual veiculação não possui mais modo e finalidade, de modo que a lembrança recorrente impacta a sua vida privada.

Desse modo, o objeto tutela de um pleito do direito ao esquecimento quando inserido em um espaço baseado em um fluxo informacional de fácil acesso como a internet, através destes motores de busca, passa a estar ligado com a proteção de dados pessoais, no sentido de controle. Desse modo, o controle autoinformativo do ambiente digital se remete as informações que foram coletadas e perderam a finalidade pelo qual motivou a sua coleta; quando o titular dos dados quiser impedir a circulação dos dados, revogando o seu consentimento ou quando o tratamento dado por um terceiro não satisfaz o titular ${ }^{43}$.

Nesse sentido, há uma tendência mundial de regulamentações acerca da ideia de proteção de dados pessoais, que já vem na mesma perspectiva das regulamentações já outrora existentes no ordenamento jurídico brasileiro: Código de Defesa do Consumidor e Marco Civil da Internet.

Na União Europeia, em 2018, entrou em vigor o Regulamento Geral sobre a Proteção de Dados 2016/679, o qual prevê em seu artigo 17 o "right to erasure ('right to be forgotten')", ou seja, em tradução literal, o direito ao apagamento de dados ('direito a ser esquecido'). O dispositivo assegura o direito ao titular obter do responsável pelo tratamento do dado o apagamento de seus dados pessoais, quando aplicar um dos motivos descritos pela lei, mas ao mesmo tempo, estabelece limitações expressas a este direito no próprio texto da lei, como interesses legítimos prevalecentes que justifiquem o tratamento, o exercício da liberdade de expressão e informação ou para fins de interesse público. No cenário europeu, o direito ao esquecimento na internet leva em consideração a arquitetura da internet

\footnotetext{
${ }^{42}$ BENEVIDES, N.; SILVESTRE, G. O Papel do Google na Eficácia do Direito ao Esquecimento - Análise Comparativa Entre Brasil e Europa. Revista de Direito Privado, v. 70, out. 2016, p. 5. ${ }^{43}$ MORAES, Melina Ferracini. O direito ao esquecimento na internet no contexto das decisões judiciais no Brasil. 2016. 140 f. Tese (Mestrado em Direito Político e Econômico) - Universidade Presbiteriana Mackenzie, São Paulo, 2016, p. 87.
} 
e como informações são construídas e ocorrem á partir dela ${ }^{44}$.Por este viés, a noção de esquecimento passa a estar ligada ao apagamento, com seus limites inerentes, tendo em vista a conjuntura informacional.

Ainda acerca do Regulamento Geral sobre a Proteção de Dados 2016/679, o artigo 18 do dispositivo propõe limitações ao tratamento de dados em determinados casos e não necessariamente uma exclusão, como disposto no artigo anterior. As hipóteses são quando o responsável pelo tratamento divulga "dados falsos ou inexatos, ou os obtém de maneira ilícita, podendo ser compelido a ajustar a situação para conformá-la com a vontade do titular dos dados." ${ }^{45}$. Assim como a exclusão, o tratamento de dados pessoais encontra condições, sendo os motivos de declaração, exercício ou defesa de um direito num processo judicial, de defesa dos direitos de outra pessoa singular ou coletiva, ou por motivos ponderosos de interesse público da União ou de um Estado-Membro.

Inspirado nas diretrizes europeias e em razão da insuficiência pelo qual as leis infraconstitucionais do ordenamento jurídico brasileiro tratam o controle sobre o uso e compartilhamento de suas informações no ambiente digital, fora sancionada em 14 de agosto de 2018, a Lei Geral de Proteção de Dados (Lei $n^{\circ}$ 13.709), que altera as disposições sobre a questão previstas no Marco Civil da Internet (Lei $\left.n^{\circ} 12.965\right)$ e entra em vigor em agosto de 2020, passando a integrar o sistema de proteção de dados pessoais do ordenamento.

A legislação estabelece disposição acerca da licitude do tratamento de dados. Segundo o artigo $7^{\circ}$, inciso IX, só é lícito aquele tratamento de dado em que não prevaleça sobre ele direitos e liberdades fundamentais de seu titular que exijam a sua proteção. Com o objetivo de assegurar o direito à vida privada assegurado na Constituição Federal, a Lei Geral de Proteção de Dados torna-se um instrumento legislativo capaz de auferir efetividade ao direito ao esquecimento reconhecido ao jurisdicionado, servindo com incentivo ao cumprimento das ordens de remoção, retificação e desindexação de conteúdo pelos provedores de aplicações de internet ${ }^{46}$.

\footnotetext{
${ }^{44}$ LEMOS, Ronaldo. Direito, tecnologia e cultura. Rio de Janeiro: FGV, 2005, p. 21.

${ }^{45}$ MORAES, Melina Ferracini. O direito ao esquecimento na internet no contexto das decisões judiciais no Brasil. 2016. 140 f. Tese (Mestrado em Direito Político e Econômico) - Universidade Presbiteriana Mackenzie, São Paulo, 2016, p. 88.

${ }^{46}$ MARTINI, Sandra Regina; BERGSTEIN, Laís. Aproximações entre o direito ao esquecimento e a lei geral de proteção de dados pessoais (LGPD). Revista Científica Disruptiva, v. 1, n. 1, p. 160176, 29 jun. 2019, p. 172-173.
} 
No entanto, a Lei Geral de Proteção de Dados também possui como fundamento em seu artigo $2^{\circ}$, inciso III a valoração da liberdade de expressão, de informação, de comunicação e de opinião. Deste modo, quando o titular se tratar de pessoa pública, de modo que a informação possuir interesse público, constituindo assim uma exceção à autodeterminação informativa. Em virtude disso, a ponderação de direitos fundamentais é necessária para a aplicação dos pleitos.

Por conseguinte, apesar de "direito ao esquecimento" não ser uma nomenclatura adequada, pode-se resumir os seus elementos no âmbito digital como a tutela ligada a diferentes hipóteses de pleito relacionadas à proteção da privacidade (retificação, remoção e desindexação), no sentido de controle dessas informações incidentes sobre os provedores de aplicação na internet, com a finalidade de desvincular-se de informações específicas e pretéritas que não condizem com a vida presente ou são vexaminosas, despidos de interesse público, mas diante de critérios a ser seguidos para a sua aplicação.

OS VALORES CONSTITUCIONAIS ENVOLVIDOS NA
TESE DO DIREITO AO ESQUECIMENTO, CRITÉRIOS
DE PONDERAÇÃO E APLICAÇÃO

\section{1}

O PRINCÍPIO DA DIGNIDADE DA PESSOA HUMANA COMO FUNDAMENTO E CARÁTER RESTRITIVO DO DIREITO AO ESQUECIMENTO

A tutela do direito ao esquecimento, como no sentido de não ser lembrado constantemente, tem como fundamento o princípio da dignidade da pessoa humana na sociedade de informação, como meio de impedir afrontas aos direitos da personalidade e proteger as "esferas essenciais de desenvolvimento e realização da pessoa humana" 47 valores essenciais ao conceito de dignidade humana e que sua aplicação, á luz do caso concreto, deve levar em conta o contexto social, no caso, a Sociedade da Informação.

Conclui-se, em um primeiro momento, que nos casos que envolvam violações a personalidade humana e a tutela do direito ao esquecimento na Sociedade de Informação, o princípio da dignidade da

47 SCHREIBER, Anderson. Direitos da personalidade. 2. ed. São Paulo: Atlas, 2013, p. 8. 
pessoa humana deve ser considerado como parâmetro de interpretação, tendo em vista a realização da pessoa humana no momento histórico em que ela está inserida ${ }^{48}$.

No entanto, quanto a sua aplicação, não dá para estabelecer a mesma amplitude a todos os direitos e garantias fundamentais que possuem intrinsecamente a proteção à dignidade da pessoa humana, porém não da mesma simetria ${ }^{49}$. Apesar do princípio da dignidade humana ser reconhecido como conteúdo e fundamento da proteção do direito à vida privada, e consequentemente do direito ao esquecimento pela sua inerência, a sua amplitude é variável. Conforme leitura do artigo $5^{\circ}$, caput, da Constituição Federal, os direitos e garantias fundamentais decorrem do "princípio da titularidade universal" 50 , ou seja, é assegurada a toda pessoa humana. Em alguns casos excepcionais, o princípio da dignidade da pessoa humana pode confrontar com outros princípios ou direitos. Como nos casos envolvendo a tutela do direito ao esquecimento e a liberdade de expressão e ou, em que o objeto da lide pelo qual o requerente pleiteia a aplicação do direito, é uma informação de cunho de interesse público.

Nesse sentido, dependendo da análise do caso concreto, por um lado, o princípio da dignidade da pessoa humana opera não só como proteção, mas como caráter restritivo a outros direitos fundamentais. Por outro lado, é vedada a restrição de direito fundamental ainda que justificada pela proteção da dignidade, quando implicar em ofensa a dignidade de quem tem o seu direito restringido ${ }^{51}$.

Por tal razão reconhecer a aplicação do direito ao esquecimento quando o objeto tratar-se de informação de cunho de interesse público, ainda que justificada pela proteção da dignidade da pessoa humana resulta restrição de direitos da sociedade, no que diz respeito à memória coletiva, assegurada pelo artigo 216, da Constituição Federal.

À vista disso, verifica-se uma estrita relação entre memória coletiva e dignidade da pessoa humana, no que diz respeito não só a dignidade individual, mas de um povo.

\footnotetext{
48 SCHREIBER, Anderson. Direitos da personalidade. 2. ed. São Paulo: Atlas, 2013, p. 8.

${ }^{49}$ SARLET, Ingo Wolfgang; MARINONI, Luiz Guilherme; MITIDIERO, Daniel. Curso de Direito Constitucional. 6. ed. São Paulo: Saraiva, 2017, p. 267.

${ }^{50}$ SARLET, Ingo Wolfgang; MARINONI, Luiz Guilherme; MITIDIERO, Daniel. Curso de Direito Constitucional. 6. ed. São Paulo: Saraiva, 2017, p. 267.

${ }^{51}$ SARLET, Ingo Wolfgang; MARINONI, Luiz Guilherme; MITIDIERO, Daniel. Curso de Direito Constitucional. 6. ed. São Paulo: Saraiva, 2017, p. 268.
} 


\subsubsection{A CONEXÃO DO DIREITO DE PROTEÇÃO À VIDA PRIVADA E A TUTELA DO DIREITO AO ESQUECIMENTO: RESSIGNIFICAÇÃO DO CONCEITO NA SOCIEDADE DE INFORMAÇÃO E A AUTODETERMINAÇÃO INFORMATIVA.}

Os direitos da personalidade estão positivados no artigo $5^{\circ}$, inciso $\mathrm{X}$ da Constituição Federal, bem como no Capítulo II do Código Civil e assumem caráter autônomo de proteção ao desenvolvimento livre da personalidade em sentido integral ${ }^{52}$. Como fundamento no princípio da dignidade da pessoa humana, é que se adota o entendimento de que os direitos da personalidade não possuem rol taxativo, seja expressamente reconhecido na Constituição Federal ou previsto na legislação infraconstitucional ${ }^{53}$, conforme também assegurado pela cláusula geral do artigo $5^{\circ}, \S 2^{\circ}$, da Constituição Federal.

Desse modo, no que tange especificamente ao direito á vida privada, é que os pleitos relacionados à tutela do direito ao esquecimento encontram-se a sua proteção e seu fundamento, mesmo sem possuir expressa previsão legal e sim por integrar a dignidade humana na sociedade de informação e em razão da previsão da cláusula geral.

A privacidade pode ser entendida como a esfera mais ampla das relações sociais do individuo, como relações familiares, pessoais, comerciais, profissionais, religiosas, entre outras. A intimidade, por sua vez, faz parte da vida privada, no entanto, se caracteriza por ser uma esfera mais restrita das relações dos indivíduos, como os segredos, relações afetivas, entre outros. Entretanto, em que pese à diferenciação, em razão da fluidez da esfera da vida privada, principalmente, na era digital, onde se perdeu a dicotomia entre a esfera pública e privada ${ }^{54}$, impõe a aferição da violação do direito à privacidade perante o caso concreto, refutando-se "toda e qualquer catalogação prévia e fechada de situações que possam se enquadrar no seu âmbito de proteção" $" 55$.

Por isso, no contexto da Sociedade da Informação e em razão da impossibilidade de se impor um conceito fechado do que seria privacidade, esta ganha concepção relacionadas à autodeterminação do indivíduo sobre

\footnotetext{
${ }^{52}$ SARLET, Ingo Wolfgang; MARINONI, Luiz Guilherme; MITIDIERO, Daniel. Curso de Direito Constitucional. 6. ed. São Paulo: Saraiva, 2017, p. 440.

53 SCHREIBER, Anderson. Direitos da personalidade. 2. ed. São Paulo: Atlas, 2013, p. 14.

${ }^{54}$ BIONI, Bruno Ricardo. Proteção de dados pessoais: a função e os limites do consentimento. 1. ed. Rio de Janeiro: Forense, 2019. p. 99.

${ }^{55}$ SARLET, Ingo Wolfgang; MARINONI, Luiz Guilherme; MITIDIERO, Daniel. Curso de Direito Constitucional. 6. ed. São Paulo: Saraiva, 2017, p. 447.
} 
o meio em que desenvolve a sua personalidade, no caso, as tecnologias digitais. O que outrora era visto somente na perspectiva dicotômica entre a esfera privada e pública, relacionada ao sigilo, deve ser enxergada também, em uma perspectiva não dicotômica, relacionada ao controle ${ }^{56}$, em razão do novo fluxo de circulações que as informações ganharam na Sociedade de Informação.

A circulação sem limites da informação acarreta violações a pessoa humana em relação "a representação de si mesma que é construída a partir de seus dados pessoais" 57 . Neste sentido, "o objeto do direito á privacidade amplia-se, como efeito do enriquecimento da noção técnica da esfera privada, a qual compreende um número sempre crescente de situações juridicamente relevantes" ${ }^{\$ 8}$. Os dados podem abranger tanto informações de cunho patrimonial, como de natureza existencial, "relacionadas à saúde, à ideologia política, à religião ou a outros aspectos íntimos da pessoa humana."

Nesse sentido, a privacidade passa a se projetar além da mera identificação do sujeito e de seus comportamentos privados e a esfera privada passa a abarcar o "conjunto de ações, comportamentos, opiniões, preferências, informações pessoais, sobre os quais o interessado pretende manter controle exclusivo" ${ }^{60}$,armazenadas no ambiente digital, sendo a privacidade entendida como uma tutela de escolha ${ }^{61}$,de construção da individualidade sem dominações externas.

Desse modo, o direito ao esquecimento se insere na seara da proteção à vida privada, no sentido de controle de dados, sem interferência em direitos de terceiros, que, em razão do tempo, se tornaram desatualizadas ou irrelevantes passando a gerar danos e impedimentos ao desenvolvimento livre de sua personalidade. Ou seja, pode-se afirmar que o "direito ao esquecimento" seria uma garantia do direito fundamental a inviolabilidade da vida privada, no mesmo sentido da inviolabilidade do domicilio e da correspondência, no entanto, no que diz respeito a uma

\footnotetext{
${ }^{56}$ BIONI, Bruno Ricardo. Proteção de dados pessoais: a função e os limites do consentimento. 1. ed. Rio de Janeiro: Forense, 2019. p. 97.

57 SCHREIBER, Anderson. Direitos da personalidade. 2. ed. São Paulo: Atlas, 2013, p. 139.

58 RODOTÁ, Stefano. A vida na sociedade de vigilância: a privacidade hoje. 1. ed. São Paulo: Renovar, 2008, p. 93.

${ }^{59}$ SCHREIBER, Anderson. Direitos da personalidade. 2. ed. São Paulo: Atlas, 2013, p. 159.

${ }^{60}$ RODOTÁ, Stefano. A vida na sociedade de vigilância: a privacidade hoje. 1. ed. São Paulo: Renovar, 2008, p. 92.

${ }^{61}$ FRIDEMAN, Lawrence. The Republic of Choice. Law, Authority and Culture, Cambridge (Mass.), 1990, p. 184.
} 
esfera privada mais ampla inserida na Sociedade da Informação, passando da ideia do sigilo ao controle ${ }^{62}$.

Ainda que a sua existência e aplicação esteja implícita no fundamento nos direitos da personalidade e da dignidade humana, em razão da característica do rol aberto, há na doutrina, a defesa do reconhecimento de um direito ao esquecimento autônomo, ou seja, a expressa previsão de um novo direito da personalidade, assim como a proteção de dados pessoais de modo geral, a fim de se desvincular do conceito e dinâmica dicotômica do direito à privacidade ${ }^{63}$ e garantir maior eficácia na aplicação do direito.

A diferenciação da problemática do direito ao esquecimento está na noção cronológica da informação, conforme expõe Daniel Bucar:

\footnotetext{
"O chamado direito ao esquecimento incorpora uma expressão do controle temporal de dados, que preenche com o fator cronológico a atual tríade de ferramentas protetivas da privacidade, complementada pelos controles espacial e contextual." ${ }^{64}$ (Grifo Nosso)
}

Nesse sentido, o direito ao esquecimento visa assegurar três tipos de proteção à privacidade, de moto interligado: espacial, contextual e temporal. Por esta razão, o reconhecimento deste direito estaria ligado a uma ressignificação da ideia de privacidade, como ligada diretamente a noção de liberdade. A presença do controle espacial visa fornecer a pessoa o controle de suas próprias informações, para que ela possa se desenvolver a sua esfera privada sem dominações externas dentro da sociedade65. Atrelado a isto, o controle contextual, que seria ter controle de que a sua informação seja revelada dentro do seu correto contexto66. Neste sentido, a privacidade passa a estar ligada também com o conhecimento. E por fim, sendo a particularidade do direito ao esquecimento, têm-se o controle

\footnotetext{
${ }^{62}$ RODOTÁ, Stefano. A vida na sociedade de vigilância: a privacidade hoje. 1. ed. São Paulo: Renovar, 2008, p. 98.

${ }^{63}$ BIONI, Bruno Ricardo. Proteção de dados pessoais: a função e os limites do consentimento. 1. ed. Rio de Janeiro: Forense, 2019, p. 100.

${ }^{64}$ BUCAR, Daniel. Controle temporal de dados: o direito ao esquecimento. Revista Civilística, ano. 2. n. 3. 2013. Disponível em: http://civilistica.com/controle-temporal-de-dados-o-direito-aoesquecimento/. Acesso em: 5 mar. 2019.

${ }^{65}$ BUCAR, Daniel. Controle temporal de dados: o direito ao esquecimento. Revista Civilística, ano. 2. n. 3. 2013. Disponível em: http://civilistica.com/controle-temporal-de-dados-o-direito-aoesquecimento/. Acesso em: 5 mar. 2019.

${ }^{66}$ BUCAR, Daniel. Controle temporal de dados: o direito ao esquecimento. Revista Civilística, ano. 2. n. 3. 2013. Disponível em: http://civilistica.com/controle-temporal-de-dados-o-direito-aoesquecimento/. Acesso em: 5 mar. 2019.
} 
temporal, no sentido de que, não basta somente o controle da autodeterminação informativa, no sentido da "faculdade de o particular determinar e controlar os seus dados pessoais"67, mas sim a possibilidade de exercer este controle após um determinado período ${ }^{68}$. Ou seja, vale ressaltar que não é um mero pedido de remoção de conteúdo e sim um pedido de remoção de conteúdo que embora, verídico e lícito, perdeu a sua finalidade com o tempo.

\section{2}

\section{A COLISÃO DO DIREITO À PRIVACIDADE COM A LIBERDADE DE EXPRESSÃO, DIREITO À INFORMAÇÃO E MEMÓRIA COLETIVA: PARÂMETROS DE APLICAÇÃO DO DIREITO AO ESQUECIMENTO.}

$\mathrm{O}$ direito ao esquecimento na internet encontra-se fundamento a partir da dignidade humana e da cláusula geral dos direitos a personalidade, relacionado a uma ressignificação da esfera privada e de sua proteção. No entanto, a problemática consiste na sua aplicação, no sentido da necessidade de definição de parâmetros prévios para que este direito não torne um instrumento de censura.

Em alguns casos, a tutela do direito ao esquecimento na internet pode colidir com outros direitos e garantias fundamentais asseguradas pela Constituição Federal e também pela legislação infraconstitucional, no Marco Civil da Internet, como é o caso da liberdade de expressão, direito ao acesso à informação e memória coletiva.

A Constituição Federal de 1988 e a legislação infraconstitucional relativo ao uso da internet no Brasil, Marco Civil da Internet (Lei $\mathrm{n}^{\circ}$ 12.965/2014), orientadas pelo princípio fundamental da dignidade da pessoa humana, asseguram o respeito á liberdade de expressão. $O$ conceito de liberdade de expressão envolve tanto o respeito á atividade intelectual, artística e científica, quanto o respeito à comunicação, conforme artigo $5^{\circ}$, inciso IX, da CF. Ou seja, em sintonia com o espaço digital, trata-se da "liberdade da pessoa humana manifestar seu pensamento, criar, se expressar e informar sob qualquer forma, processo ou veículo, inclusive a

\footnotetext{
${ }^{67}$ CANOTINHO, José Joaquim Gomes. Direito Constitucional e Teoria da Constituição. Coimbra: Almedina, 2000, p. 468.

${ }^{68}$ BUCAR, Daniel. Controle temporal de dados: o direito ao esquecimento. Revista Civilística, ano. 2. n. 3. 2013. Disponível em: http://civilistica.com/controle-temporal-de-dados-o-direito-aoesquecimento/. Acesso em: 5 mar. 2019.
} 
internet." ${ }^{69}$. Neste sentido digital, a liberdade de comunicação envolve a liberdade de se expressar e divulgar opinião por palavra escrita e imagem, de se informar livremente por todos os meios lícitos, bem como de ser informado sobre temas de interesse público pelo Estado e meios de comunicação e a liberdade de imprensa ${ }^{70}$.

Assim como outros direitos fundamentais, apesar de ser orientada pela dignidade da pessoa humana, é nela que encontra os seus limites. Desse modo, as liberdades comunicativas não são incondicionais e absolutos, devendo ser exercidos de forma compatibilizada e harmônica com outros direitos e garantias fundamentais previstos na Constituição Federal.

As liberdades comunicativas são precedentes e fundamentais para a garantia da memória coletiva, que também é assegurada pela Constituição Federal, no artigo 216, com relevância de "patrimônio cultural da sociedade", que pode ser definido como "toda produção o humana de ordem emocional intelectual e material independentemente de sua origem, época ou aspecto formal bem como a natureza, que propiciem o conhecimento e a consciência do homem sobre si mesmo e sobre o mundo que o rodeia." 71 .Para isto, o direito à informação abarca uma proteção ampla de modo a abranger todas as questões que apresentam interesse público, a fim de proteger a memória coletiva. Neste sentido, o conceito de interesse público é bem amplo e maleável, como dispõe Daniel Sarmento afirmando que este "deve ser concebido de maneira alargada, para abranger a mais ampla variedade de matérias que tenham relevo para a vida social" ${ }^{72}$.

Neste sentido, a preservação da memória coletiva está ligada aos elementos que constroem a história da sociedade, para que além da finalidade de identificação das convicções de um povo, de modo plural, este aprenda com o passado para não cometer os erros do presente, especificamente em relação aos elementos que possuem cunho democrático.

\footnotetext{
${ }^{69}$ FIORILLO, Celso Antônio Pacheco. O Marco Civil da Internet e o Meio Ambiente Digital na Sociedade de Informação: comentários à Lei no 12.965/2014. São Paulo: Saraiva, 2015, p. 19.

${ }^{70}{ }^{70}$ FIORILLO, Celso Antônio Pacheco. O Marco Civil da Internet e o Meio Ambiente Digital na Sociedade de Informação: comentários à Lei no 12.965/2014. São Paulo: Saraiva, 2015, p. 20.

71 GODOY, Maria. Patrimônio cultural: conceituação e subsídios para uma política In: ENCONTRO ESTADUAL DE HISTÓRIA E HISTORIOGRAFIA EM MINAS GERAIS, 4, 1985. Anais ... Belo Horizonte: ANPUH, 1985.

72 SARMENTO, Daniel. Liberdades Comunicativas e "Direito ao Esquecimento" na ordem constitucional brasileira. Revista Brasileira de Direito Civil. v. 7, n. 01, jan-mar. 2016, p. 10.
} 
Tendo em vista que na era digital a democracia é exercida através do fluxo de informações presente na internet, é fundamental que as liberdades comunicativas prosperem neste espaço para a sua efetiva garantia. A partir dela, os cidadãos podem participar das discussões políticas de modo a fiscalizar os governantes e detentores do poder social ${ }^{73}$. Como consequência, para fins de reconhecimento e aplicação do direito ao esquecimento, é difícil conceituar com clareza o que seria interesse público. Segundo Celso Antônio Bandeira de Mello, a informação de interesse público deve ser um veiculo de realização de interesses atuais e futuros ${ }^{74}$. Neste sentido, "deve ser conceituado como o interesse resultante do conjunto dos interesses que os indivíduos pessoalmente têm quando considerados em sua qualidade de membros da Sociedade e pelos simples fato de o serem.". Ou seja, o interesse público envolve o interesse pessoal de cada um, no entanto, enquanto membro de uma sociedade e os valores amplos de proteção ligados a uma coletividade a qual estão inseridos, um conjunto social. Bem como, uma informação de cunho de interesse público não perde a sua característica em razão do tempo ${ }^{75}$. Assim como, informações que podem parecer irrelevantes ou desatualizadas no momento pode não ser mais amanhã, como é o caso de processos judiciais (LEMOS, 2014). É necessário sempre que possível, a ponderação destes direitos, escolhendo a medida menos danosa, considerando uma posição preferencial da liberdade de expressão, em um ordenamento jurídico que valoriza a História, sendo a liberdade de expressão caráter instrumental para a garantia de outros direitos ${ }^{76}$.

Neste contexto, cabe analisar e diferenciar interesse público de interesse do público. Enquanto a primeira se trata de relevante valor social, de forma que a sua veiculação e o seu conteúdo são necessários a expressar o interesse social de modo a construir a história, a segunda trata-se de uma veiculação sensacionalista, comercial, que remete a execração pública e estigma social. Nestes casos, é válida a limitação das liberdades comunicativas em prol do livre desenvolvimento da personalidade do

\footnotetext{
73 SARMENTO, Daniel. Liberdades Comunicativas e "Direito ao Esquecimento" na ordem constitucional brasileira. Revista Brasileira de Direito Civil. v. 7, n. 01, jan-mar. 2016, p. 6.

${ }^{74}$ BANDEIRA DE MELLO, Celso Antônio. Curso de Direito Administrativo. 32.ed. São Paulo: Malheiros, 2015, p. 62.

75 SARMENTO, Daniel. Liberdades Comunicativas e "Direito ao Esquecimento" na ordem constitucional brasileira. Revista Brasileira de Direito Civil. v. 7, n. 01, jan-mar. 2016, p. 31.

76 SARMENTO, Daniel. Liberdades Comunicativas e "Direito ao Esquecimento" na ordem constitucional brasileira. Revista Brasileira de Direito Civil. v. 7, n. 01, jan-mar. 2016, p. 25.
} 
indivíduo, para que, no mínimo, o fato seja retratado de maneira digna, caso ele possua interesse público.

Acrescenta-se, no que tange a efetivação do direito ao esquecimento, que esta é dificultada pelo chamado "Efeito Streisand", que se deve a premissa de que "quanto mais se deseja o esquecimento, mais se desperta a curiosidade alheia e mais a memória ativa"77. O fenômeno possui este nome, pois se deve a tentativa da "atriz e cantora Barbra Streisand ter tentando remover uma foto de sua casa de um site alegando preocupações com sua privacidade e, em razão disso, o site viu um aumento considerável de visitas de usuários que queria ver a referida foto."78. Neste sentido, é possível o indivíduo tutelar pleitos relacionados ao direito, mas este não pode assegurar o seu esquecimento de fato, principalmente pessoas públicas. Neste viés, analisa-se que, em tempos de internet, a tentativa censura é possível e arriscada, mas dificilmente pode passar despercebida.

Para evitar o risco do direito ao esquecimento se tornar regra, e não exceção é necessário estabelecer alguns parâmetros gerais, mesmo que alguns pareçam subjetivos dependendo da análise do caso concreto. Primeiramente, a informação do direito ao esquecimento deve ser de natureza verídica e privada, sem interesse para sociedade; em decorrência do tempo, perdeu o modo e finalidade pelo qual foi veiculada; pode acarretar risco de dano moral, familiar, patrimonial, profissional; mesmo sendo de interesse público, deve ser veiculada de modo essencial a relevância histórica, não importando em sensacionalismo, sendo necessárias medidas para conjugar a liberdade de expressão e direitos da personalidade.

A conjugação de direitos deve ser feita usando a técnica e ponderação, por meio dos critérios de razoabilidade e proporcionalidade, de modo que não haja anulação de nenhum direito. Neste sentido, pode se aplicar medidas alternativas para atingir a finalidade de não ser lembrado recorrentemente, sem causar riscos à liberdade de expressão. Alguns exemplos disso são a aplicação de um direito de resposta ou atualização da informação ${ }^{79}$, em contraposição a um pleito do direito ao esquecimento, poderia ser medidas eficazes.

\footnotetext{
${ }^{77}$ BRANCO, Sérgio. Memória e esquecimento na internet. $1^{\circ}$. ed. Porto Alegre - RS: Arquipélago Editorial LTDA., 2017, p. 146.

${ }^{78}$ BRANCO, Sérgio. Memória e esquecimento na internet. $1^{\circ}$. ed. Porto Alegre - RS: Arquipélago Editorial LTDA., 2017, p. 146.

${ }^{79}$ BRANCO, Sérgio. Memória e esquecimento na internet. $1^{\circ}$. ed. Porto Alegre - RS: Arquipélago Editorial LTDA., 2017, p. 180.
} 


\section{O DIREITO AO "ESQUECIMENTO" NA INTERNET SOB A ÓTICA DAS DECISÕES JUDICIAS DO SUPERIOR TRIBUNAL DE JUSTIÇA}

Com base nos dados e reflexões colhidas nos capítulos anteriores, o presente capítulo busca a extrair os elementos pertinentes nas decisões judiciais do Superior Tribunal de Justiça. Para isto, através de pesquisa no banco de dados na respectiva Corte com o termo "direito ao esquecimento internet", foi selecionado, entre os cinco resultados, dois acórdãos que possuem em comum o expresso pleito do direito ao "esquecimento" a pessoas físicas no ambiente digital: Agravo Interno no Recurso Especial 1.593.873 - SP (2016/0079618-1) e Recurso Especial 1.660.168 - RJ (2014/0291777-1). Bem como, ambos os casos são relativos aos limites da responsabilidade dos provedores de aplicações de busca na internet pelo conteúdo dos respectivos resultados em frente ao direito ao esquecimento.

O primeiro caso trata-se especificadamente de um pleito de desindexação das imagens de nudez da requerente dos resultados do provedor de pesquisa Google. Quanto ao segundo, por sua vez, trata-se de um pleito realizado por uma Promotora de Justiça de desindexação nos resultados dos provedores de busca mantidos pela Google, Yahoo e Microsoft de notícias relacionadas às suspeitas de fraude no XLI Concurso da Magistratura do Estado do Rio de Janeiro.

Nos dois casos selecionados, os requerentes alegam que o fácil acesso as informações trazem danos a sua dignidade e privacidade, impedindo o livre desenvolvimento de suas personalidades. No entanto, apesar de suas similaridades, os julgamentos foram distintos quanto ao provimento do tratamento de dados relativos aos provedores de busca, apesar de reconhecerem a existência do direito ao esquecimento.

O Agravo Interno no Recurso Especial 1.593.873 - SP (2016/0079618-1) fora julgado em 2016 e firmou que demanda deve ser em face do provedor de conteúdo, pois é ele quem armazena o fato. Desse modo, para garantir a tutela de um "esquecimento", a requerente deve indicar a URL específica, conforme preceitua o artigo $19, \S 1^{\circ}$ do Marco Civil da Internet.

Essa decisão foi julgada no mesmo sentido de outro precedente relativo ao Caso Xuxa $\left(\operatorname{RE~}^{\circ} 1.316 .921 / \mathrm{RJ}\right)^{80}$, definindo que o provedor

\footnotetext{
${ }^{80}$ BRASIL. STJ. RECURSO ESPECIAL. REsp No 1.316.921 - RJ (2011/0307909-6). Relator: Ministro Nancy Andrighi. DJe: 29/06/2012. Disponível em:
} 
de pesquisa se limita a indicar os links encontrados a partir das palavraschaves fornecidas pelos próprios usuários, isentando-se de responsabilização. Em parâmetro com a decisão proferida no caso Mario Costeja pelo Tribunal de Justiça Europeu, o acordão alegou impossibilidade de aplicação da solução ao caso brasileiro, em razão da ausência de lei específica para proteção de dados pessoais dos brasileiros. Neste sentido, afastou a responsabilidade do "Google Search", rejeitando "imputar ao provedor de buscas a obrigação de fiscalizar o conteúdo acessível ao público" $"$.

Em contraste com o julgamento mencionado, em 2018, fora julgado o segundo caso selecionado: Recurso Especial 1.660.168 - RJ (2014/0291777-1). A Corte através do voto vencedor do Ministro Marco Aurélio Belizze, definiu posição contrária a decisão judicial citada, em caráter de excepcionalidade ${ }^{82}$.

Ao contrário do voto da Relatora Ministra Nancy Andrighi, fundamentou a pretensão de obtenção da restrição de tratamento de dados possui base legal, pois o sistema jurídico brasileiro tutela a proteção de dados dos cidadãos brasileiros através do habeas data e Lei 9.507/97, além das legislações do Código de Defesa do Consumidor e Marco Civil da Internet, em seu artigo 11, protegendo a privacidade, salvo em casos de interesse público.

Afirmou que nos casos que denotem ausência de razoabilidade na exibição dos resultados, é necessária a apreciação do Poder Judiciário para resguardar aquelas informações eminentemente particulares ou que resultaram de longo prazo decorrido desde o fato que deu ensejo à inclusão dos dados pessoais apontados na busca.

Ressaltou o pleito em questão é restrito ao apontamento de seu nome, como critério exclusivo, desvinculado de qualquer outro termo, diferentemente dos outros casos julgados pelo STJ. Desse modo, o Ministro em seu voto vencedor, deu parcial provimento ao recurso para afastar da busca direcionada ao nome da requerente os resultados que

\footnotetext{
https://scon.stj.jus.br/SCON/jurisprudencia/toc.jsp?livre=XUXA\&tipo_visualizacao=RESUMO\&b= ACOR\&thesaurus=JURIDICO\&p=true. Acesso em: 1 mar. 2019.

${ }^{81}$ BRASIL. STJ. AGRAVO INTERNO NO RECURSO ESPECIAL. AgInt no REsp No 1.593.873 SP (2016/0079618-1). Relator: Ministro Nancy Andrighi. DJe: 17/11/2016. Disponível em:https://ww2.stj.jus.br/processo/revista/inteiroteor/?num_registro=201600796181\&dt_publicacao= 17/11/2016. Acesso em: 20 ago. 2019.

${ }^{82}$ BRASIL. STJ. RECURSO ESPECIAL. REsp No 1.660.168 - RJ (2014/0291777-1). Relator: Ministro Nancy Andrighi. DJe: 05/06/2018. Disponível em: https://ww2.stj.jus.br/processo/revista/inteiroteor/?num_registro=201402917771\&dt_publicacao=05/ 06/2018. Acesso em: 20 ago. 2019.
} 
indicam fatos desabonadores noticiados há uma década. No entanto, através de uma conjugação entre direito à privacidade e livre acesso á informação, manteve acessível o conteúdo em suas fontes, de forma que as suas buscas deverão conter palavras-chave relativas ao conteúdo.

\section{CONSIDERAÇÕES FINAIS}

A Sociedade de Informação, em sua era digital, trouxe um novo dinamismo às circulações da informação, através da tecnologia "bits" e dos provedores de serviços de internet. Deste modo, este dinamismo trouxe características qualitativas e quantitativas à informação em razão de sua instantaneidade, amplitude em seu alcance, possibilidade de armazenamento ilimitado, de modo que uma informação possa permanecer por um tempo indefinido no ambiente digital, bem como pelo seu fácil acesso, através da tecnologia utilizada pelos provedores de busca.

Diante disso, a dicotomia tradicional caracterizada pela esfera privada e esfera pública passou a ter novos significados quando transposta ao meio digital. Os indivíduos passaram a compartilhar informações pessoais no espaço público da internet ou tiveram informações relacionadas a si próprio propagadas por terceiros nesta esfera, sendo presente o consentimento ou não.

Diante da dificuldade de controle sobre o alcance da informação em um meio digital, em razão de suas características, a relação entre memória e esquecimento em relação a informações pessoais do indivíduo fora transformada.

Como consequência, surgem novos conflitos em relação à pessoa humana e a exposição de suas informações pessoais de modo indeterminado, de modo a afetar o seu livre desenvolvimento da personalidade. Este contexto remonta a tese do direito ao esquecimento, que possui as suas origens no instituto da ressocialização dos indivíduos condenados que cumpriram a sua pena e desejam se vir livres de estigmas sociais, através da não veiculação dos fatos na mídia. Atualmente, a discussão analisada sobre o prisma do ambiente digital, abarca-se não são informações relacionadas à esfera penal, bem como a esfera cível também.

Desta forma, o direito ao "esquecimento" passa a tutelar de modo geral o desejo do individuo de ter remover, retificar ou desindexar determinada informação que diz respeito a si próprio, está veiculada pelo espaço cibernético e perdeu a finalidade pelo qual era veiculada, em razão 
do lapso temporal, tornando-se irrelevante ou desatualizada. As reticências utilizadas se remetem ao fato que o termo "esquecimento" é equivocado, principalmente quando a sua aplicação se concentra no espaço digital. A tecnologia digital, considerando a forma pelo qual as informações são difundidas e muito menos o próprio Direito, não pode assegurar uma exclusão definitiva de alguma informação. De modo que nem a própria pessoa humana pode se prometer esquecer-se de algo, visto que isto é um fator biológico.

Por essa razão, a ideia de direito ao "esquecimento" no ambiente digital está ligada a não ter algum fato sendo relembrado constantemente pela opinião pública, para que a pessoa possa desenvolver a sua personalidade sem limitações externas.

Existe a controvérsia sobre qual seria o fundamento do direito ao esquecimento no ordenamento jurídico. O fato de não existir um dispositivo específico tratando da matéria, somente aproximações, não constituí óbice ao reconhecimento do direito ao esquecimento dentro do ordenamento jurídico brasileiro, porém pode implicar em dificuldades quanto a sua aplicação e efetivação.

Primeiramente, o ordenamento jurídico não é moldado somente a partir da dogmática da lei, possuindo valores que o norteiam, os chamados princípios. Tendo em vista isto, segundo parecer apresentado "Aída Curi" (RE 1010606/RJ) pela Procuradoria Geral da República, reconhece esta visão ao afirmar que o direito ao esquecimento seria um desdobramento do direito á privacidade, assegurado pela inviolabilidade da vida privada previsto na Constituição Federal de 1988.

É possível esta associação visto que os direitos da personalidade constituem cláusula geral, abrangendo todo tipo de violação ao livre desenvolvimento da personalidade.

No entanto, tendo em vista a perda da dicotomia da esfera pública e privada no âmbito digital e diante das dificuldades técnicas da rede de se impor uma exclusão definitiva da informação, não se pode ligar esse conflito e sua respectiva solução a uma ideia de sigilo, como o conceito tradicional e dicotômico da privacidade e sim a ideia de controle autoinformativo, ou seja, controle acerca das informações que dizem respeito à própria pessoa humana, como define o jurista italiano Stefano Rodotá, ressignificando a privacidade na ideia de uma tutela de escolha e liberdade.

Desse modo, apesar de poder fundamentar o direito ao esquecimento com base no direito à proteção da vida privada, é importante 
ressaltar a noção de que o seu conceito tradicional é insuficiente para tratar as demandas em frente à estrutura da internet. Neste sentido, do mesmo modo que autores defendem a criação de um direito de proteção de dados autônomo, por este mesmo viés, é necessária a previsão expressa do direito ao esquecimento no âmbito digital, para tutelar também o controle temporal das informações, quando em razão disso perderam o modo e a finalidade pelos quais são veiculadas. Esta tutela está vinculada a dignidade da pessoa humana, bem como, encontra nela as suas restrições.

Nesse sentido, ressalta-se a necessidade de também definir parâmetros do que pode ser obscuro do público, geram outros conflitos com valores constitucionais, envolvendo a liberdade de expressão, direito á informação e memória coletiva.

Tendo em vista que o ordenamento jurídico brasileiro se funde em um Estado Democrático de Direito este, por sua vez, tem como premissa para atingir as suas finalidades a proteção dos Direitos Fundamentais em sua totalidade. Por isto, considerando que possuem status de direitos fundamentais e estes possuem o mesmo valor axiológico, não são absolutos. Como consequência, como em todo hard case, é necessária à aplicação da técnica de ponderação e as soluções específicas serão definidas diante do caso concreto, á partir dos elementos e fatos a ele inerentes. Nenhum deles irá ser anulado, mas algum terá sua prevalência, aplicado em maior ou menor grau. Bem como, o Judiciário ao julgar casos concretos envolvendo a tese do direito ao esquecimento na internet, deve ter como premissa inicial a arquitetura da rede e as consequências advindas dela, definindo medidas que possibilitem a aplicação de modo a balancear ambos os direitos.

Para nortear a interpretação do Judiciário, é válido o estabelecimento de parâmetros relacionados ao conceito de interesse público, principalmente aqueles envolvendo fatos relevantes ou que podem ser a vir relevante a Administração Pública, a afim de que a medida não se torne regra e sim exceção. Acrescenta-se que, a defesa de uma legislação expressa que trate do direito ao esquecimento, a exemplo do Regulamento Geral sobre a Proteção de Dados 2016/679 da União Europeia, é importante, pois não só dá um maior alcance e efetividade a este direito, como estabelece limites específicos a sua aplicação, não deixando margens para discricionariedade. 


\section{REFERÊNCIAS}

AMARAL, João Ferreira do. Economia da informação e do conhecimento. 10. ed. Coimbra: Almedina, 2007.

BANDEIRA DE MELlO, Celso Antônio. Curso de Direito Administrativo. 32.ed. São Paulo: Malheiros, 2015.

BENEVIDES, Nauani Shades; SILVESTRE, Gilberto Fachetti. O Papel do Google na Eficácia do Direito ao Esquecimento - Análise Comparativa Entre Brasil e Europa. Revista de Direito Privado. Revista de Direito Privado. São Paulo: Editora Revista dos Tribunais. v. 70, p. 99-122, out. 2016.

BIONI, Bruno Ricardo. Proteção de dados pessoais: a função e os limites do consentimento. 1. ed. Rio de Janeiro: Forense, 2019.

BRANCO, Sérgio. Memória e esquecimento na internet. $1^{\circ}$. ed. Porto Alegre - RS: Arquipélago Editorial LTDA., 2017.

BRASIL. Constituição (1988). Constituição da República Federativa do Brasil. Disponível em: http://www.planalto.gov.br/ccivil_03/Constituicao/Constituicao.htm. Acesso em: 10. mar. 2019.

Lei $\mathrm{n}^{\circ} 12.965$, de 23 de abril de 2014. Estabelece princípios, garantias, direitos e deveres para o uso da Internet no Brasil. Brasília, DF, 24 abr. 2014. Disponível em: http://www.planalto.gov.br/CCIVIL_03/_Ato2011-2014/2014/Lei/L12965.htm. Acesso em: 10. mar. 2019.

. Lei $n^{\circ}$ 13.709, de 14 de agosto de 2018. Dispõe sobre Lei Geral de Proteção de Dados. Brasília, DF, 15 ago. 2018. Disponível em: http://www.planalto.gov.br/ccivil_03/_Ato20152018/2018/Lei/L13709.htm. Acesso em: 10. mar. 2019.

Lei $\mathrm{n}^{\circ}$ 8.078, de 11 de setembro de 1990. Dispõe sobre a proteção do consumidor e dá outras providências. Brasília, DF, 12 set. 1990. Disponível em:

http://www.planalto.gov.br/ccivil_03/leis/18078.htm. Acesso em: 10. mar. 2019.

Superior Tribunal de Justiça. Agravo Interno no Recurso Especial. AgInt no REsp No

1.593.873 - SP (2016/0079618-1). Relator: Ministro Nancy Andrighi. DJe: 17/11/2016.

Disponível

em:https://ww2.stj.jus.br/processo/revista/inteiroteor/?num_registro=201600796181\&dt_publicacao= 17/11/2016. Acesso em: 20 ago. 2019.

Superior Tribunal de Justiça. Recurso Especial. REsp No 1.660.168 - RJ (2014/0291777-1).

Relator: Ministro Nancy Andrighi. DJe: 05/06/2018. Disponível em:

https://ww2.stj.jus.br/processo/revista/inteiroteor/?num_registro=201402917771\&dt_publicacao=05/ 06/2018. Acesso em: 20 ago. 2019.

Superior Tribunal de Justiça. Recurso Especial. REsp No 1.316.921 - RJ (2011/0307909-6).

Relator: Ministro Nancy Andrighi. DJe: 29/06/2012. Disponível em: https://scon.stj.jus.br/SCON/jurisprudencia/toc.jsp?livre=XUXA\&tipo_visualizacao=RESUMO\&b= ACOR\&thesaurus=JURIDICO\&p=true. Acesso em: 1 mar. 2019. 
Superior Tribunal de Justiça. Recurso Especial. REsp No 1.334.097 - RJ (2012/0144910-7).

Relator: Ministro Luis Felipe Salomão. DJe: 10/09/2013. Disponível em:

https://ww2.stj.jus.br/processo/revista/documento/mediado/?componente=ATC\&sequencial=3100651 $0 \&$ num_registro $=201201449107 \&$ data $=20130910 \&$ tipo $=5 \&$ formato $=P D F$. Acesso em: 1 mar. 2019.

BUCAR, Daniel. Controle temporal de dados: o direito ao esquecimento. Revista Civilística, ano. 2. n. 3. 2013. Disponível em: http://civilistica.com/controle-temporal-de-dados-o-direito-aoesquecimento/. Acesso em: 5 mar. 2019.

CANOTILHO, José Joaquim Gomes. Direito Constitucional e Teoria da Constituição. Coimbra: Almedina, 2000.

CASTELLS, Manuel. A sociedade em rede. 3. ed. São Paulo: Paz e Terra, 2000.

DAHMER, André. Quadrinho dos anos 10. 1. ed. São Paulo: Quadrinhos na cia, 2016.

FIORILlO, Celso Antônio Pacheco. O Marco Civil da Internet e o Meio Ambiente Digital na Sociedade de Informação: comentários à Lei nº 12.965/2014. São Paulo: Saraiva, 2015.

FREUD. Sigmund. O mal-estar na civilização. São Paulo: Penguin Classics Companhia das Letras, 2011.

FRIDEMAN, Lawrence. The Republic of Choice. Law, Authority and Culture, Cambridge (Mass.), 1990.

GODOY, Maria. Patrimônio cultural: conceituação e subsídios para uma política In: ENCONTRO ESTADUAL DE HISTÓRIA E HISTORIOGRAFIA EM MINAS GERAIS, 4, 1985. Anais ... Belo Horizonte: ANPUH, 1985.

INTERNETLAB. Direito ao esquecimento: entre liberdade de expressão e direitos da personalidade. Entrevista com Julia Powles. Disponível em: http://www.internetlab.org.br/wpcontent/uploads/2017/01/ENTREVISTA_JULIA_POWLES_v04.pdf. Acesso em: 2 jul. 2019.

ITS RIO. Amicus curiae - Direito ao Esquecimento no STF. Disponível em: https://itsrio.org/wpcontent/uploads/2018/05/amicus-curiae-instituto-tecnologia-direito-ao-esquecimento.pdf. Acesso em: 20 nov. 2018.

IZQUIERDO, Iván. Memória. 2a ed. Porto Alegre: ArtMed, 2002.

LEMOS, Ronaldo. Direito, tecnologia e cultura. Rio de Janeiro: FGV, 2005.

Direito ao esquecimento é mais veneno que remédio. Disponível em:

https://www.conjur.com.br/2014-mai-20/ronaldo-lemos-direito-esquecimento-veneno-remedio. Acesso em: 10 jul. 2019.

MARTINI, Sandra Regina; BERGSTEIN, Laís. Aproximações entre o direito ao esquecimento e a lei geral de proteção de dados pessoais (LGPD). Revista Científica Disruptiva, v. 1, n. 1, p. 160176, 29 jun. 2019. 
MORAES, Melina Ferracini. O direito ao esquecimento na internet no contexto das decisões judiciais no Brasil. 2016. 140 f. Tese (Mestrado em Direito Político e Econômico) - Universidade Presbiteriana Mackenzie, São Paulo, 2016.

ORWELL, George. 1984. 9. ed. São Paulo: Companhia das Letras, 2017.

PAESANI, Liliana Minardi. O direito na sociedade de informação.. 1. ed. São Paulo: Atlas, 2007.

PINHEIRO, Patricia Peck. Direito Digital. 6. ed. São Paulo: Saraiva, 2018.

RODOTÁ, Stefano. A vida na sociedade de vigilância: a privacidade hoje. 1. ed. São Paulo: Renovar, 2008.

SARLET, Ingo Wolfgang; MARINONI, Luiz Guilherme; MITIDIERO, Daniel. Curso de Direito Constitucional. 6. ed. São Paulo: Saraiva, 2017.

SARMENTO, Daniel. Liberdades Comunicativas e "Direito ao Esquecimento" na ordem constitucional brasileira. Revista Brasileira de Direito Civil. v. 7, n. 01, jan-mar. 2016.

SCHREIBER, Anderson. Direitos da personalidade. 2. ed. São Paulo: Atlas, 2013.

TECMUNDO. O que é Bit?. Disponível em: https://www.tecmundo.com.br/programacao/227-o-quee-bit-.htm. Acesso em: 8 ago. 2019.

TED. Why Privacy Matters?. Disponível em:

https://www.ted.com/talks/glenn_greenwald_why_privacy_matters?language=pt-br. Acesso em: 5 jul. 2019.

UE. General Data Protection Regulation 2016/679. 27 abr. 2016. Disponível em: http://www.privacy-regulation.eu/pt/index.htm. Acesso em: 10. mar. 2019. 